\title{
Permian-Triassic maturation and
} multistage migration of hydrocarbons in the Assistência Formation (Irati Subgroup), Paraná Basin, Brazil: implications for the exploration model

\author{
Maturação permotriássica e os vários estágios de migração de \\ hidrocarbonetos na Formação Assistência (Subgrupo Irati), Bacia \\ do Paraná: implicações para os modelos exploratórios
}

António Mateus ${ }^{1}$, Claudio Riccomini ${ }^{2,3}$, Ezequiel J. E. C. B. Ferreira ${ }^{3}$, Colombo C. G. Tassinari ${ }^{2,3}$

\begin{abstract}
New lines of geological evidence strongly suggest that the main period of hydrocarbon maturation within Assistência Formation should be Permian-Triassic, stimulated by a high geothermal gradient that also sustained various manifestations of hydrothermal activity. Three main stages of fluid/hydrocarbon migration can also be inferred on the basis of multiscale observations: confined flow in late Permian to Triassic times, depending on the local build-up of fluid pressures; heterogeneous flow in Lower Cretaceous, triggered by a rejuvenated temperature gradient assisted by the early developed permeability conditions; and a late flow possibly driven by local pressure gradients, after complete cooling of dolerite dykes/sills. The early maturation and multistage migration of hydrocarbons have significant consequences in the design of exploration models to be applied in Paraná Basin.
\end{abstract}

KEYWORDS: Hydrocarbon; Maturation; Generation; Assistência Formation; Permian-Triassic; Paraná Basin; Brazil.
RESUMO: Novas linhas de evidências geológicas sugerem fortemente que o principal período de maturação de hidrocarbonetos na Formação Assistência teria ocorrido no Permotriássico, estimulado por um gradiente geotérmico elevado que também sustentou várias manifestaçóes de atividade hidrotermal. Três fases principais de migração de fluidos e hidrocarbonetos também podem ser inferidas a partir de observaçóes em multiescala: fluxo confinado no final do Permiano ao Triássico, dependente do acúmulo local de pressóes de fluidos; fluxo heterogêneo no Cretáceo Inferior, desencadeado por um gradiente de temperatura rejuvenescido, assistido pelas condiçốes de permeabilidade antes desenvolvidas; e um fluxo tardio, possivelmente impulsionado por gradientes de pressáo locais, posteriormente ao esfriamento dos diques e soleiras de diabásio. A maturaçáo precoce e a existência de vários estágios de migração de hidrocarbonetos apresentam implicaçôes significativas na concepção de modelos exploratórios a serem aplicados na Bacia do Paraná.

PALAVRAS-CHAVE: Hidrocarbonetos; Maturação; Geração; Formação Assistência; Permotriássico; Bacia do Paraná; Brasil.

\footnotetext{
${ }^{1}$ Departamento de Geologia e CeGUL, Faculdade de Ciências, Universidade de Lisboa, Lisboa, Portugal. E-mail: amateus@fc.ul.pt

${ }^{2}$ Instituto de Energia e Ambiente e Instituto de Geociências, Universidade de São Paulo - USP, São Paulo (SP), Brazil. Research fellow of Conselho Nacional de Desenvolvimento Científico e Tecnológico,Brazil.E-mails: riccomin@usp.br; ccgtassi@iee.usp.br

${ }^{3}$ Programa de Pós-Graduação em Geoquímica e Geotectônica, Instituto de Geociências, Universidade de São Paulo - USP, São Paulo (SP), Brazil. E-mail: ezequielferreira@usp.br

*Corresponding author.
}

Manuscrito ID: 30163. Recebido em: 19/09/2014. Aprovado em: 19/09/2014. 


\section{INTRODUCTION}

Black-shales in the late Permian Assistência Formation (sensu Hachiro et al. 1993) are envisaged as the main source of oil and asphalt occurrences observed either within sequence (as fracture-controlled showings) or in the above sandstones of Piramboia Formation (as local, but strong, porous impregnations) (e.g. Araújo et al. 2000). The main period of hydrocarbon maturation is usually ascribed to Lower Cretaceous as a result of the high-thermal regime correlative of the important magmatic activity, which affected the Paraná Basin for ca 8-10 Ma (Turner et al. 1994), and subsequent migration pathways often attributed to several fracture arrays depending on the mechanical response of the anisotropic multilayer sequence to local stress fields imposed by the emplacement and cooling of dolerite dykes/ sills (e.g. Araújo et al. 2000; Araújo et al. 2005). The critical arguments that support this geological model rely on the common observation that, close to dykes/sills, the rhythmic succession of black-shales and dolomitised mudstone layers display strong mineralogical and textural modifications, which include notable variations of the total organic carbon (TOC) values. These secondary processes promote the development of metasomatic aureoles of variable extension around the igneous bodies, whose characteristics are functions of the medium porosity/permeability and its chemical reactivity, as well as the temperature of the rising magma and subsequent cooling rate.

There is a generalised belief that the diagenetic thermal gradient affecting the sedimentary basin before the Lower Cretaceous magmatic event is rather low, reaching maximum temperatures of 60 to $80^{\circ} \mathrm{C}$ (Araújo 2001). In this sense, authigenic clay minerals formed from hydrothermal fluids in sandstones of the Permian Rio Bonito (Brazil) and San Miguel (Paraguay) formations present a dominant Early Cretaceous age linked with the Serra Geral magmatic event, although late Permian ages were also reported (Sant'Anna et al. 2006).

The inspection of well-exposed sections of the Assistência Formation in different mines distributed in a large area without record of dolerite dykes/sills (Itapetininga, PereirasCesário Lange, and Saltinho-Tietê, Fig. 1) show, however, that other lines of evidence should be considered to explain the known oil and asphalt occurrences. These observations together with preliminary data already gathered for samples collected in places where the sedimentary succession is affected by several dolerite sills (e.g. Partecal mine, Rio Claro, Fig. 1) show the need of revisiting the existing geological model and carefully assessing the implications on hydrocarbons exploration in the Paraná Basin resulting from the integration of new data.

\section{DIAGENESIS AND HYDROTHERMALISM}

Far from intrusive rocks of any kind, the rhythmic/multilayer package of black-shales and carbonate rocks included in the Assistência Formation preserve mineral compositions and textural arrangements, suggesting that a relatively high geothermal gradient should have affected the sedimentary basin long before the dolerite dykes/sills emplacement (i.e. during the Permian-Triassic time-window). The prevailing evidence include:

an overall enrichment of black-shales in $\mathrm{Mg}$ - and Fe-smectites (saponite and nontronite, respectively) coupled with a variety of other authigenic and neoformed phases, such as silica or microcrystalline quartz, pyrite, calcite and fine-grained aggregates of other clay minerals not completely unravelled at present;

- the occasional preservation of effects due to carbonate dissolution/re-precipitation with the creation of secondary porosity in thin-banded mudstones only partially dolomitised;

the heterogeneous progression of dolomitisation of preexistent mudstones, further affected by silicification along irregular fronts (Fig. 2A) that, in many places, are controlled by effective porosity gradients and discrete fractures set at right angles with stratification;

- the presence of millimetre to centimetre thick chert and/ or flint layers (occasionally continuous), often coupled by the growth of silica spherules/concretions mostly along contacts between silicified dolostones and layers of clay-rich mudstones or black-shales;

- the late (and restricted) formation of hydraulic breccias controlled by local increases of pore fluid pressures at the headwall of thicker layers of dolomitised mudstones, which frequently show wavy geometry; and

- the multiphase development of microcrystalline quartz + calcite \pm phyllosilicate fracture infillings cross-crossing the original multilayer sequence, variably dolomitised and/or silicified.

Many of these features can be observed in sections of the Assistência Formation affected by the emplacement of dolerite dykes/sills; however herein, as expected, they are modified as a consequence of a range of chemical reactions progressed under higher temperature conditions in domains adjoining the igneous bodies. Therefore, the growth of recrystallisation products driven by thermal conduction and mass diffusion mechanisms is common, although in some places it is plausible to admit the involvement of limited heat and mass advection. After complete cooling of dolerite dykes/sills, a renewed event of fracturing and concomitant 


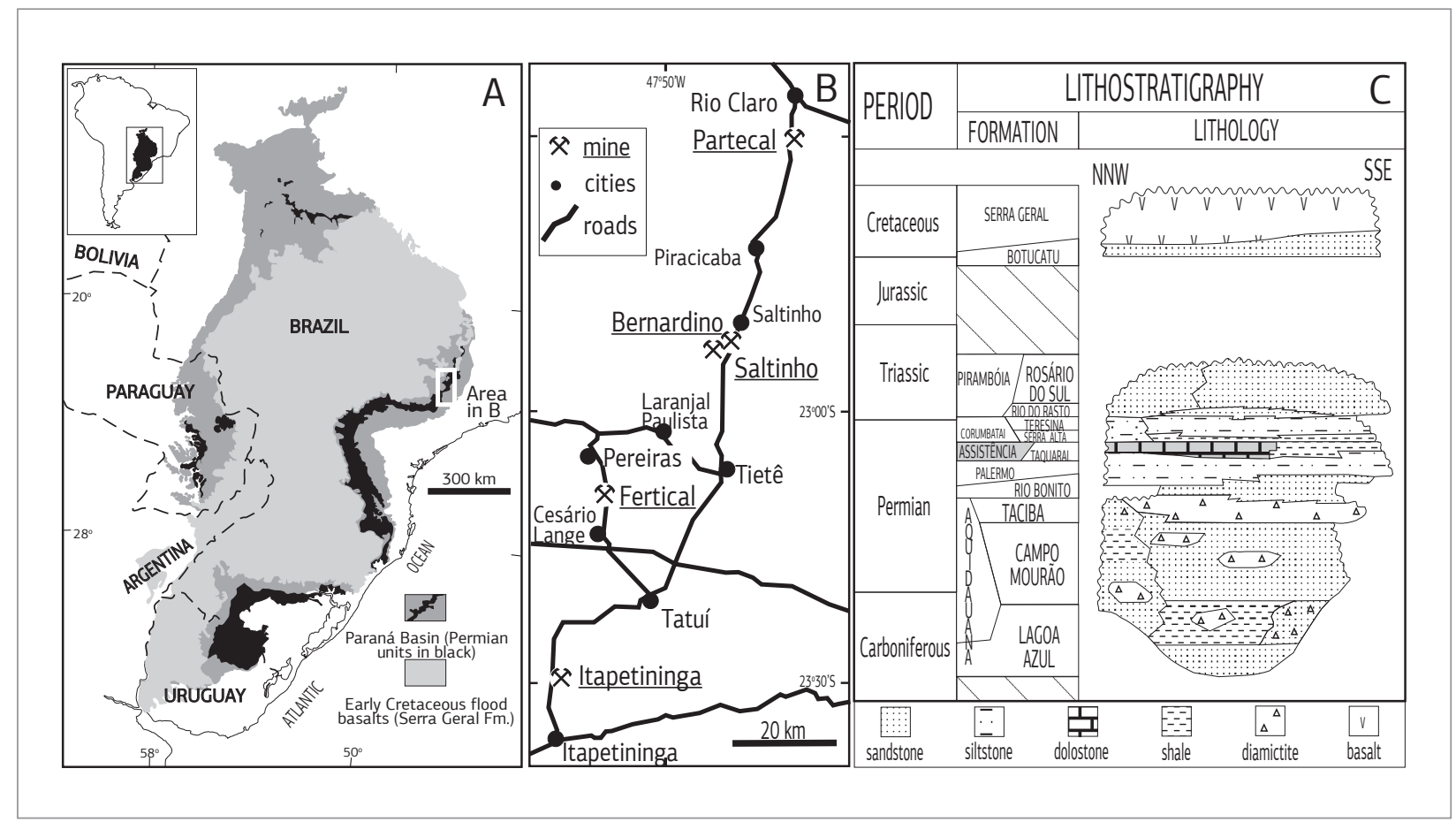

Figure 1. (A) Simplified geological map of Paraná Basin (modified from Sant'Anna et al. 2006) with indication of the study area (rectangle); (B) open pit mines referred in the text; (C) lithostratigraphic chart of the Paleozoic and Mesozoic sections of Paraná Basin (modified from Sant'Anna et al. 2006).

fluid circulation can be inferred based on diverse structural and mineralogical features macroscopically similar to those above mentioned and clearly affecting the igneous bodies.

\section{MATURATION AND MULTISTAGE MIGRATION OF HYDROCARBONS}

The processes sustained and/or favoured by the early high geothermal gradient (that in the deeper parts of the basin may have reached temperatures up to $125^{\circ} \mathrm{C}$ ) should yielded effects of regional significance. Actually, these can be correlated with several manifestations of intense silica deposition, in addition to thin horizons of volcanic-ashes observed in some sections of the Assistência Formation (recording a contemporary magmatic activity, localised elsewhere in the Paraná Basin or adjoining areas; e.g. Rocha-Campos et al. 2011). The former manifestations are well preserved in many places at the base of the Assistência Formation, close to the contact with the Taquaral Formation, as well as on top of the Teresina/Serra Alta formations, preceding the regressive period during which the continental eolian sandstones of Piramboia Formation were produced. Some of these siliceous chemiogenic occurrences are fault-related, documenting episodic discharges of silica-saturated fluids channelized into crustal discontinuities during the tectonic instability imposed to the Paraná Basin in the PermianTriassic times. Many other occurrences, however, represent fields of multi-focused hydrothermal fluid discharges (like the geyserite preserved at Saltinho mine, Fig. 2B) or diffuse exhalative-hydrothermal activity with no evident macro/ meso-structural confinement, but ruled by the grain-scale (anisotropic) permeability and giving rise to heterogeneous silicification of the affected stratigraphic succession.

The referred processes easily generated adequate conditions to sustain significant interstitial fluid flow within basin, also stimulating a large-scale maturation of the organic matter formerly trapped in fine-grained siliciclastic-dominated successions. Acting together, noteworthy advances in many chemical reactions responsible for high dissolution rates of coexisting mudstones (conceivably higher than their cementation), could have been achieved, promoting the observed dolomitisation by means of thermal convection mechanisms, and followed by widespread silica deposition and hydrocarbon redistribution. The latter could be confined to primary discontinuities (such as stratification) and early secondary porous networks related to dolomitisation or other chemical processes able to locally increase the medium permeability (Figs. 2C and 2D). Nonetheless, in the presence of a multilayer sequence composed of sediments with contrasting permeability values, the local build-up of high fluid pressures can readily be accomplished (Fig. 3); therefore, producing 

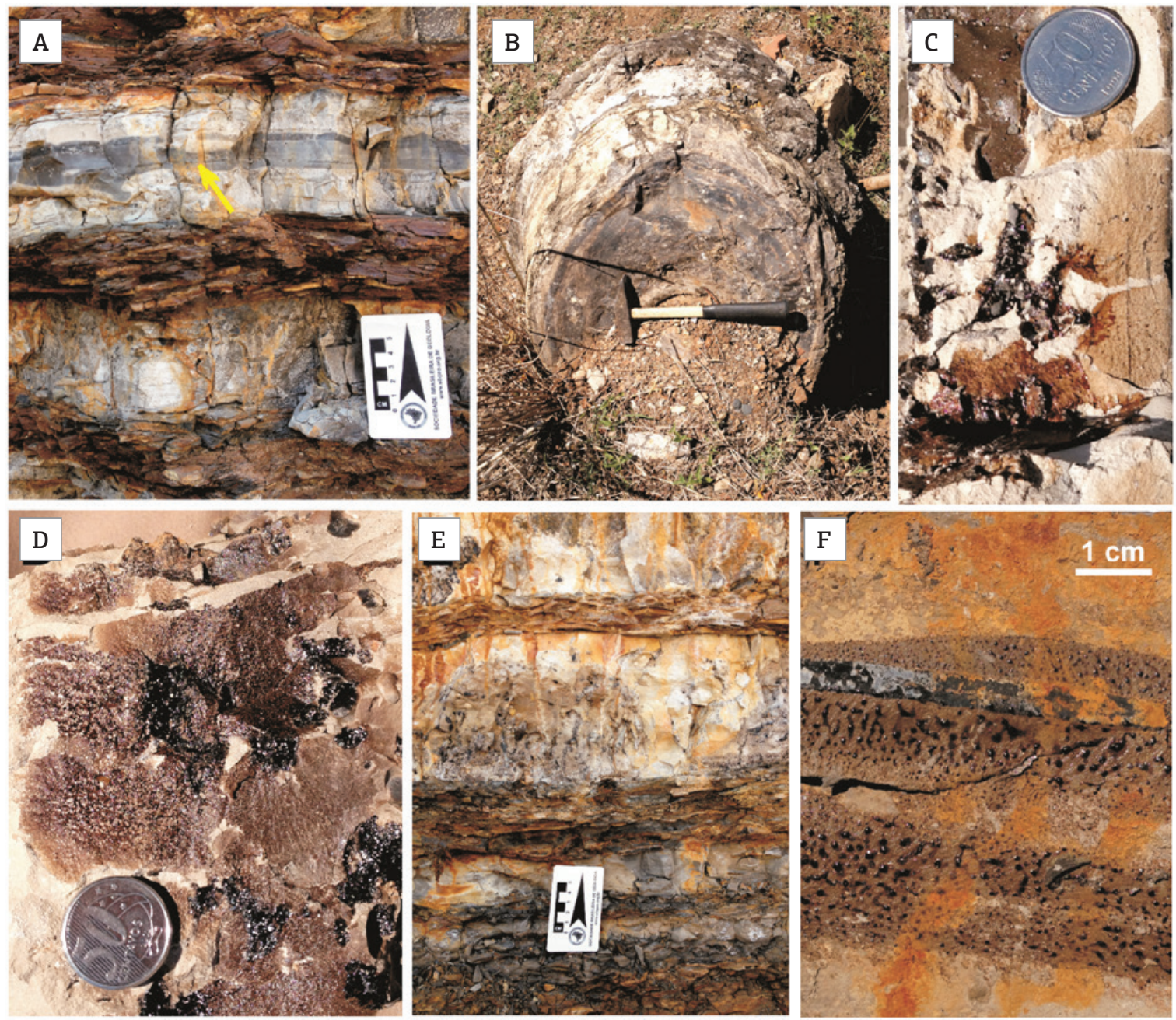

Figure 2. (A) Silicification (arrow) along irregular fronts in mudstone, Saltinho; (B) geyserite, Saltinho; (C) bitumen in secondary porosity (cavities), Bernardino; (D) bitumen in secondary porosity (cavities), Saltinho; (E) fractures disposed orthogonally to mudstone layers, Saltinho; (F) bitumen in a NE-oriented, sub-vertical extensional plumose (hackle plume) joint, Itapetininga.

physical conditions suitable for assisting a lengthy, but persistent, fluid/hydrocarbon migration throughout the sedimentary succession in late Permian times.

Hydraulic fracturing explains many features observed regarding oil/asphalt resettlement along irregular cracks or anastomosed fracture arrays (sporadically undisputable breccias; Fertical mine, Pereiras), which affect a restricted number of thin layers or are confined to domains of thicker competent strata adjoining contacts with black-shales. Further propagation of these discontinuities, possibly speeded up during the late stress relaxation experienced by the stratified massif in Triassic times, led to a regular and closed-spaced sub-vertical fracturing running NE-ENE in azimuth, and they could reinforce the hydrocarbon migration in some sections of the Assistência Formation (Figs. 2E and
$2 \mathrm{~F})$. Late stages of fracture development might have affected particular domains of Teresina/Serra Alta Formations, supporting episodic fluid/hydrocarbon flow along the upper levels of the lithostratigraphic succession, and this could be the ultimate cause of asphalt showings so far surveyed in Piramboia Formation, but never recognised in the overlying Botucatu sandstones of Lower Cretaceous age.

The high thermal regime imposed to Paraná Basin in Lower Cretaceous times should have caused a rejuvenation of the fluid/hydrocarbon flow, primarily triggered by temperature gradients. In domains subjected to high-temperature conditions (namely in those where the multiphase emplacement of dolerite dykes/sills took place), most of the existent oil was converted into gas that quickly moved into compartments of the stratigraphic succession, under 


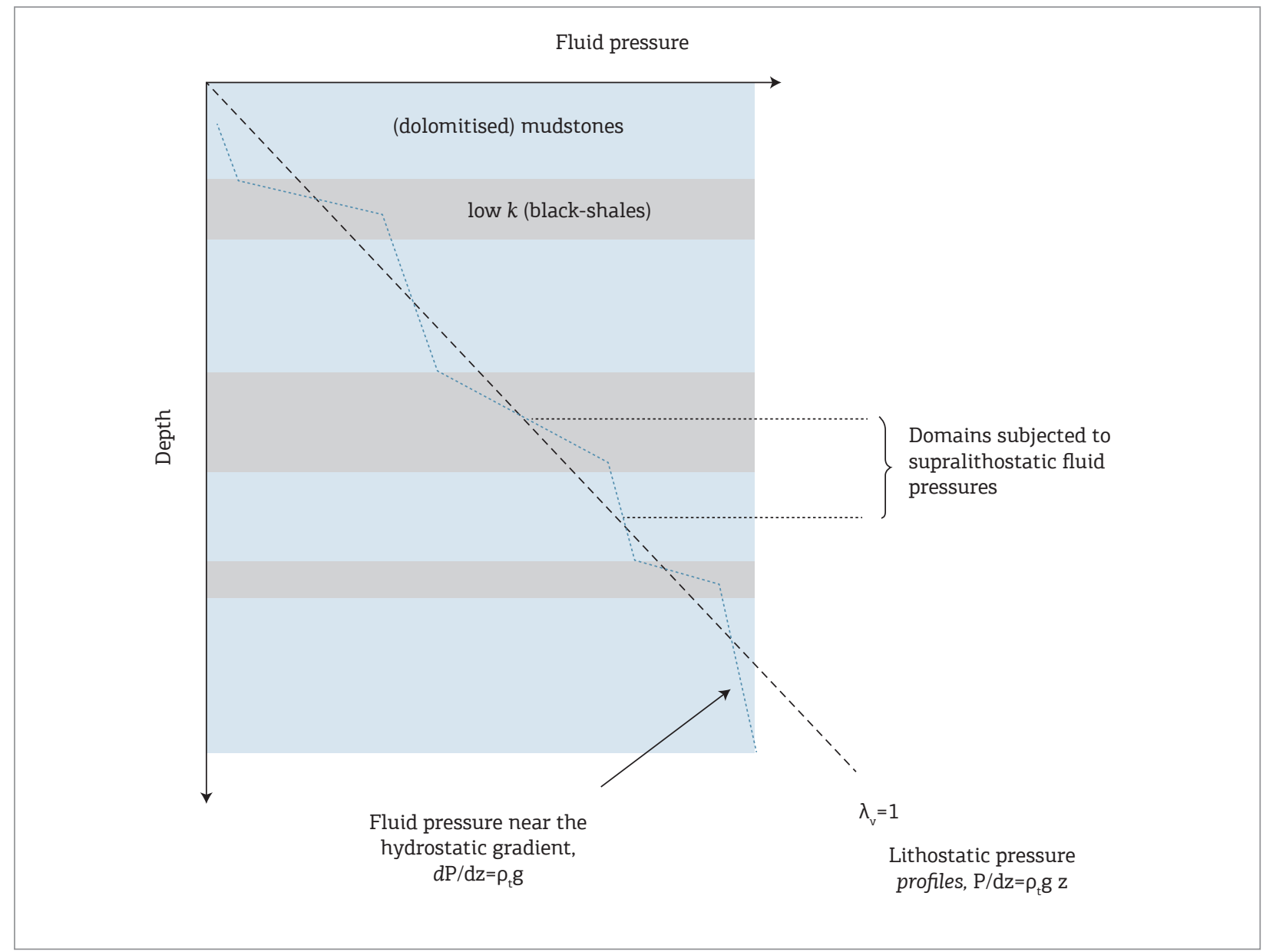

P: pressure; z: depth; g: gravity acceleration; $\rho_{\mathrm{r}}$ and $\rho_{\mathrm{f}}$ : rock and fluid density, respectively.

Figure 3. Schematic representation of rock domains subjected to supralithostatic fluid pressures in a multilayer sequence composed of rocks with strong contrasting permeability $(k)$; which will be the places where hydraulic fracturing is largely favoured.

lower temperature (and pressure) conditions. The pathways supporting fluid/hydrocarbon flow at this second stage of hydrocarbon migration in the Assistência Formation largely benefited from the permeability conditions early developed. However, in places where the build-up of fluid pressure is possible, new fractures could be formed, reinforcing the density and connectivity of suitable conduits for efficient drainage.

The very late fractures cutting through dolerite bodies and their host rocks represent the prevailing channels of the third (and limited?) stage of fluid/hydrocarbon flow within Assistência Formation. As reported, these fractures quite often demonstrate zoned mineral infillings equilibrated with compositionally different fluids as suggested by the available isotopic data. They record multiple events of opening and sealing that also assist some oil migration, possibly triggered by local pressure gradients in response to late readjustments of the stratified massif after the complete removal of thermal intumescences related to the Lower Cretaceous magmatic activity.

\section{CONCLUSIONS}

The main period of hydrocarbon maturation within Assistência Formation should be Permian-Triassic, stimulated by a high geothermal gradient that also sustained different manifestations of hydrothermal activity (from diffuse to multifocused or fault-controlled discharges). Concurrently, some black-shales and clay-rich mudstones might become enriched in several metals because of various processes, acting independently or together, namely: syn-sedimentary enrichment from sluggish seawater under anoxic, sulphate reducing conditions, episodically replenished by upwelling oxidising seawater; or syn- to late sedimentary infiltration of diffuse dense metal and hydrocarbon-rich hydrothermal fluids.

The first stage of fluid/hydrocarbon migration is relatively confined and dependent on the local build-up of fluid pressures, but strong enough to convert some sections bearing abundant carbonate rocks into fissured reservoirs. 
Suitable conditions for a renewal fluid/hydrocarbon flow should have been attained in Lower Cretaceous times, taking advantage of the temperature gradients, meanwhile established, and of the early developed permeability conditions. This second migration stage proceeded differently in sections of the Assistência Formation subjected to multiphase emplacement of dolerite dykes/sills, involving firstly the conversion of existent oil into gas and then its relocation in other compartments of the sedimentary sequence. The third stage of (limited?) fluid/hydrocarbon flow within Assistência Formation took place after complete cooling of dolerite dykes/sills, possibly driven by local pressure gradients. After this late migration stage, the ensemble made of Assistência-Teresina/Serra Alta Formations should have behaved as a regional aquitard, covered by important aquifer systems (Piramboia and Botucatu Formations). Therefore, in the presence of adequate permeability, infiltration of freshwaters might have occurred, enhancing the decomposition of existent organic matter by anaerobic microbes (methanogenesis) at low $\left(<50^{\circ} \mathrm{C}\right)$ temperature conditions.
If formed, this gas could migrate and feed other sections of the Permian-Triassic sedimentary sequence. Thus, the possibility of mixture between "biogenic" and "thermogenic" gas cannot be discarded.

These results support a new line of investigation with significant implications on the exploration model applied to Paraná Basin. Work in progress, based on a multidisciplinary approach, will provide some light to these issues, but most importantly it will for sure generate many other new questions to be answered.

\section{ACKNOWLEDGEMENTS}

The authors acknowledge the support of this research by Conselho Nacional de Desenvolvimento Cientifico e Tecnológico (CNPQ) PVE grant \#402797/2012-4, Science Without Frontiers Programme, to Mateus; and National Institute of Science and Technology of Analytical Techniques Applied to Oil and Gas Exploration (INCT) Petrotec, to Tassinari.

\section{REFERENCES}

Araújo C.C., Yamamoto J.K., Rostirolla S.P., Madrucci V., Tankard A. 2005. Tar sandstones in the Paraná Basin of Brazil: structural and magmatic controls of hydrocarbon charge. Marine and Petroleum Geology, 22:671-685.

Araújo L.M. 2001. Análise da expressão estratigráfica dos parâmetros de geoquímica orgânica nas seqüências seposicionais Irati. PhD Thesis, Universidade Federal do Rio Grande do Sul, Porto Alegre, 307 p.

Araújo L.M., Trigüis J.A., Cerqueira J.R., Freitas L.C.S. 2000. The atypical Permian petroleum system of the Paraná Basin, Brazil. In: Mello M.R. \& Katz B.J. (eds.) Petroleum systems of South Atlantic margins. Tulsa, AAPG Memoir 73, p. 377-402.

Hachiro J., Coimbra A.M., Matos S.L.F. 1993. O caráter cronoestratigráfico da Unidade Irati. In: $1^{\circ}$ Simpósio sobre cronoestratigrafia da Bacia do Paraná. Rio Claro, Resumos, p. 62-63.
Rocha-Campos A.C., Basei M.A., Nutman A.P., Kleiman L., Varela R. Lambias E., Canile F.M., Rosa O.C.R. 2011. 30 million years of Permian volcanism recorded in the Choiyoi igneous province (W Argentina) and their source for younger ash fall deposits in the Paraná Basin: SHRIMP U-Pb zircon geochronology evidence. Gondwana Research, 19:509-523

Sant’Anna L.G., Clauer N., Cordani U.G., Riccomini C., Velázquez V.F., Liewig N. 2006. Origin and migration timing of hydrothermal fluids in sedimentary rocks of the Paraná Basin, South America. Chemical Geology, 230:1-21.

Turner S., Regelous M., Kelley S., Hawkesworth C., Mantovani M. 1994. Magmatism and continental break-up in the South Atlantic: high precision 40Ar-39Ar geochronology. Earth and Planetary Science Letters, 121:333-348.

Arquivo digital disponível on-line no site www.sbgeo.org.br 